\title{
What Is Unseen On-Screen: A Descriptive Study on Students' Speaking Anxiety During Online Learning
}

\author{
Intan Kusumawardhani ${ }^{*}$ and Hernina Dewi Lestari ${ }^{2}$ \\ ${ }^{1}$ Department of English Language Teaching, State University of Malang, Indonesia and ${ }^{2}$ Department of \\ English Language Teaching, IKIP Budi Utomo Malang, Indonesia \\ *: k.intan91@gmail.com
}

\begin{abstract}
The idea of a good speaker should endeavor fluent yet accurate speaking might arise students' anxiety during the speaking performance, especially for EFL students. It would drive them either to prepare and perform their best or make them even worse. This state is known as Foreign Learning Speaking Anxiety (FLSA) and could hit anyone when speaking or communicating in the target language with several factors. During the existence of online learning, anxiety in speaking class might be one that is unseen on-screen. This study is aimed at describing the speaking anxiety faced by undergraduate students in speaking English during online learning and the strategies used to cope with speaking anxiety before and during the speaking performance. The participants in this study were 27 students of IKIP Budi Utomo Malang, consisting of 17 students of the Public Speaking class and 10 students of the Advanced Speaking class. To obtain the data, the questionnaire was conducted to know students' kinds of anxiety and their strategy to deal with it before and during the speaking performance. The results showed that the students feel anxious because of four factors, namely fear of negative evaluation, test anxiety, and anxiety in online speaking classes. The anxiety could be seen from the unclear sentences produced, sweating, butterflies in the stomach, dry mouth, loss of words, and squeaky voice. However, students take notes, do self and peer-practice before the performance; and focus on the speaking materials and breathing management during speaking performance to release the anxiety.
\end{abstract}

Key words: Descriptive, online learning, speaking anxiety.

\section{Introduction}

After the closure of some schools due to the Coronavirus Disease (COVID)-19 outbreak, education in Indonesia has made a comeback by implementing online learning. The ripple effects triggered both teachers and learners to be ready in integrating technology in online classes. Although the Covid-19 National Task Force has allowed face-to-face learning to be administered in some areas with the green zone (13\%) [1], there was still a bigger number of those who should learn from home (87\%) in the even semester of 2020-2021. Hence, the majority was still applying online learning as the new form of education. It is also possible that this mode of teaching would last any longer in the future since we have stepped on the technology this far. There are some things to ponder in online learning; namely, the change of teachers behaviors, teaching/learning style, assessment methods [2], low digital literacy, lack of devices, 
poor internet connection [3], and these might affect students' attitudes, interaction, motivation, and cooperation due to their little experience with this form of teaching [3] [4]. The aforementioned points could evoke students' anxiety in learning; one of the foreign language anxieties faced by the students is in speaking skills.

During the process of EFL language learning at a higher level, speaking skills could be a token showing the overall learning progress. In the communicative output, the main purpose in speaking is learners try to complete a task, such as obtaining information, developing a travel plan, or creating a video [5]. To complete the task, they may use the language that has been presented by the lecturers. Moreover, they also may dig up on any other vocabulary, grammar, and communication strategies. As the output of a good speaker, the main point is when the ideas are delivered clearly so that they can be accepted well in accordance with what is wanted by the listeners [4]. Accuracy is not a consideration unless the lack of it interferes with the message [5]. Some students might make the most of their effort to deliver the message, notwithstanding they are fighting against anxiety. In this face-to-screen era, it is still possible to feel anxious in speaking though we are facing the screen. What unseen on-screen lead this study to explore deeper how students manage their anxiety behind their screen is.

According to Krashen as cited in [6], there are a number of affective elements that contribute to second language acquisition. However, the most encountered elements are motivation, self-confidence, and anxiety. A number of previous studies nailed on students' anxiety in speaking, which varied the variables: senior high school students [4] [7]-[9], university students in Indonesia [10]-[13], in Japan [14], pre-service English teachers in Indonesia [15], and gender in Turkish [16]. The varied findings were prompted; posited on various factors. For example in senior high school. It is mentioned that the students were dealing with speaking anxiety during distance learning [4]. In addition, the students had various ways to heal the anxiety. While [7] study differed from [4] in a way that speaking anxiety affected in a negative way to the students. Yet, the students also find their way of coping with their anxiety. While other works, also mentioned many students were at the "Mildly Anxious" level and no student with the "Very Relaxed" [8]. And the last in senior high level was reported that on average, learners indicated a moderate-to-serious level of FLSA [9]. In their study, both anxious and non-anxious learners evaluated the learning websites applied by the teachers positively and seemed to embrace web-based language learning for their speaking practice. When interviewed, learners also seemed to believe that their speaking anxiety can be reduced by means of language learning websites. To sum up, the previous studies in senior high school students showed that the students were anxious in practicing speaking; still and all, they have their own ways to relax their feelings.

The results of previous studies are in line with those who take the university students as the object of the study, that is most of the students felt anxious in speaking class (see [10]-[12]). Those also projecting on the factors that triggered the speaking anxiety, differ between those who applied distance learning and face-to-face learning. For instance, in face-to-face learning, the source of the participants' speaking anxiety is self-perception or self-esteem, presentation in the classroom, fear of making mistakes, social environment, gender [10] [13] [16], culture differences, and formal classroom environment [10], feeling under pressure dealing with people, feeling worried about negative evaluation by teachers, and worrying about losing faces [7] [15]. While previous studies that were conducted in online learning had different factors. Those are technology literacy, the internet, devices, materials, material delivery, assignments, feedback, and assessment [4] [11]. Yet, the students' feelings behind the screen have not to be discussed. The integration of technology in the online classroom has been done for almost three semesters, and it makes both students and teachers are used to it. Thus, since it is no longer something new, then this study aimed at describing university students' speaking anxiety during online learning. The research questions are: (i) What kinds of anxiety are faced by university students in speaking English during online learning? (ii) What are the strategies used by the students to cope with anxiety in speaking English during online learning?

\section{Method}

Descriptive study was employed in this study because this research was more concerned with the 'what' question rather than how or why something has happened. The goal of descriptive research is to describe a phenomenon and its characteristics [17]. The data were collected using a questionnaire as the instrument. The questionnaire consisted of 41 questions; 40 close-ended and 1 open-ended question. This study adapted and modified the Foreign Language Classroom Anxiety Scale questionnaire (FLCAS) by Howitz and Young (1991 as cited in [8]) which is commonly applied to determine the level of anxiety. The FLCAS was based on a five-point Likert scale, ranging from 1 (strongly disagree) to 5 (strongly agree). This scale originally consisted of 33 questionnaire items which were categorized into communicative anxiety, fear of negative evaluation, test anxiety, and anxiety of English class or classroom (at point number 4, we modified 'anxiety of English class or classroom' into 'anxiety of speaking class'). The questionnaire involved 33 statements, which were divided into the following categories: 8 items $(1,9,14,18,24,27,29,32)$ were linked to communication anxiety, 9 items $(3,7,13,15,20,23,25,31,33)$ to fear of negative evaluation, and 5 items $(2,8,10,19,21)$ to test anxiety. Whereas the 11 items remained, they were organized as anxiety of speaking classes (Zhao, 2007 as cited in [11]). In this study, the questions were added by 7 questions related to the students' feelings in an online class $(34,36,39)$, students' preparation before Speaking Class (40), and students' technology literacy (37, 
38). The last, question number 41 related to what did students do before and during online meetings in Speaking Class to cope with their anxiety.

This research was undertaken at IKIP Budi Utomo Malang. The subjects of the research were the 27 students of the English Language Teaching Department, who were taking Advanced Speaking Class (10 students) and Public Speaking Class (17 students). As the background, all respondents were having speaking classes online. They were experiencing online class/distance learning since the beginning they entered the university. Thus, the respondents were all familiar with Edlink as the Learning Management System (LMS) used by the campus. By this LMS, the suitable application for Speaking Class that has been integrated with Edlink was Zoom. The lecturer combined synchronous and asynchronous teaching techniques in teaching speaking. The activities were in form of a direct explanation of the materials via Zoom and students' speaking video as the assignments. In Zoom meetings, the lecturer presented the materials based on the topics. After that, questions and answers sessions were done. Then, the students were asked to record their speaking video and submit it in the Edlink, so that could be traced by the lecturer. In this phase, the lecturer assessed students' speech one by one, including the pronunciation, transfer of information, gestures, as well as accuracy.

To answer research questions, a questionnaire was distributed online via Google Form. The questionnaire was distributed to find out kinds of students' speaking anxiety (40 questions) and ways students did to heal their anxiety before and during the speaking performance (1 question). After the data were gained, then it was analyzed and interpreted based on the theory.

\section{Findings and Discussion}

With the adapted and modified questionnaire by Horwitz and Cope (as cited in [8]), as previously mentioned, then the gathered data were classified into four kinds of anxiety. Those were communication apprehension, fear of negative evaluation, test anxiety, and anxiety on online speaking class. The statements of the questionnaire has been adjusted to the current situation. From the gathered data, the classification of four were described based on the highest percentage for each items. The researchers pictured the representative of positive and negative responses for each classification in Table 1.

The first category is communication anxiety. The students' responses were varied, but the majority mentioned they feel moderately anxious to speak in online speaking class $(81.5 \%)$. Even so, the respondents felt moderately anxious to speak English with native speaker ( $51.9 \%$ ) and confessed that they needed more than five times practicing individual speech to calm them down before the test $(48.1 \%)$. However, there were more than half participants get nervous when they did not understand words delivered by the lecturer (55.6\%). This findings confirmed previous studies which pointed out that students were having anxiety issues in speaking during distance learning [4], particularly in moderate level [8]. Considering the quantity students needed in practicing self-speaking and their apprehension if they unable to understand words delivered by the lecturer showed that students were dealing with linguistics issues [15]. They felt like they were lack of grammar or structure, limited vocabulary, or bad English pronunciation so that they practiced it more and more in order to cope with the anxiety. In reference to that, we can see that communication apprehension was related to linguistic factor. This linguistic issue has become a serious problem for students to speak in English [15], thus it is understandable that limited vocabulary mastery would be the reason why someone worried.

Secondly, in fear of negative evaluation, majority of the students keep thinking that other students were better at English (44.4\%). It indicated that most of the students were having low self-perception. Other than that, more than half respondents felt moderately anxious to volunteer answers during online class discussion (55.6\%). The reason mostly because they felt embarrassed. It determined that the students were having moderate level of self-confidence. This self-confidence level also affected their feelings that they were afraid whenever the lecturer ready to correct every mistake they would make (37\%). Other reason that dragged the students' anxiety was that they got nervous when the lecturer asked questions which they have not prepared in advance $(55.6 \%)$. Those responses seconded the idea that people with low self-esteem worried about what their peers think [10]. Moreover, they are concerned with pleasing others. It is also called as social factor affecting anxiety [15].The impact varied as positive and negative depended on how the individual maintained on the evaluation. It could be positive if it triggered students to practice more. It could be negative if it distracted students' attention and evoked apprehension.

Third, the test anxiety faced by the students. In this study, most of them felt moderately at ease during tests in online speaking class $(66.7 \%)$. However, they still felt anxious even if they have prepared for speaking class $(51.9 \%)$. This statement showed that students' were having self-esteem and self-confidence issues. But, they spirit to attend speaking class was high, as seen from the responses that they were strongly disagree to feel like not going to speaking class $(96.3 \%)$. In addition, the students did not feel pressure to prepare very well for speaking class (51.9\%). It means that they were willing to give effort in order to succeed the class.

The last is feeling anxious during online speaking class. This kind of anxiety was seen during the class. Almost half of the respondents said that they were moderately tremble when they know they were going to be called on speaking class via Zoom (40.7\%). There were some assumptions that they would feel anxious because of the new 
media used in teaching speaking. Surprisingly, most of them mentioned that they felt more comfortable to practice speaking by recorded-video (46.2\%) and mildly anxious to speak directly using Zoom (66.7). However, even they were used to administer the online media, but they were rarely speaking English with stranger via Zoom or video call.

Table 1. Result of Students' Responses on Speaking Anxiety during Online Learning

\begin{tabular}{|c|c|c|c|}
\hline Kinds of Anxiety & Questionnaire Items & Majority Responses & Percentage (\%) \\
\hline \multirow{4}{*}{$\begin{array}{l}\text { Communication } \\
\text { hension }\end{array}$} & 18. I feel confident when I speak in online speaking class. & Neutral & 81.5 \\
\hline & 14. I would not be nervous speaking in English with native speaker. & Neutral & 51.9 \\
\hline & $\begin{array}{l}\text { 23. I need more than five times practicing individual speech to calm } \\
\text { me down before the test. }\end{array}$ & Agree & 48.1 \\
\hline & $\begin{array}{l}\text { 29. I get nervous when I do not understand every word the lecturer } \\
\text { says. }\end{array}$ & Agree & 55.6 \\
\hline \multirow[t]{4}{*}{$\begin{array}{l}\text { Fear of Negative Evalua- } \\
\text { tion }\end{array}$} & $\begin{array}{l}\text { 7. I keep thinking that the other students are better at English than I } \\
\text { am. }\end{array}$ & Agree & $44 \cdot 4$ \\
\hline & 13. It embarrasses me to volunteer answers during class discussion & Neutral & 55.6 \\
\hline & 19. I am afraid that the lecturer is ready to correct every mistake I make. & Neutral & 37 \\
\hline & $\begin{array}{l}\text { 33. I get nervous when the lecturer asks questions which I have not } \\
\text { prepared in advance. }\end{array}$ & Agree & 55.6 \\
\hline \multirow[t]{4}{*}{ Test Anxiety } & 8. I am usually at ease during tests in Speaking Class. & Neutral & 66.7 \\
\hline & 16. Even if I am well prepared for Speaking Class, I feel anxious about it. & Agree & 51.9 \\
\hline & 17. I often feel like not going to Speaking Class. & Strongly disagree & 96.3 \\
\hline & 22. I don't feel pressure to prepare very well for Speaking Class. & Agree & 51.9 \\
\hline \multirow[t]{4}{*}{$\begin{array}{l}\text { Anxiety on Online Speak- } \\
\text { ing Class }\end{array}$} & $\begin{array}{l}\text { 3. I tremble when I know that I am going to be called on Speaking Class } \\
\text { via Zoom. }\end{array}$ & Neutral & 40.7 \\
\hline & 34. I feel more comfortable to practice speaking by recorded-video. & Agree & 46.2 \\
\hline & I feel comfortable to speak directly using Zoom. & Neutral & 66.7 \\
\hline & I often speak in English with Stranger via Zoom or video call & Disagree & 40.7 \\
\hline
\end{tabular}

From the result of open-ended questionnaire, it was recorded that the students mentioned some ways they did to calm the anxiety. Those could be summed up in three activities. First, students were preparing the upcoming topics before class by jotting down some vocabularies related to the topics and practicing in front of the camera or mirror so that they felt ready for tomorrow classes. Second, during the class, students tried to forget other thoughts, which were not related to the speaking class, and always think positively. From the questionnaire, it also can be concluded that students were technology savvy and did not have any obstacles in running the application. Third, the students suggested themselves to be more confident and relax. Those added more values in online learning in terms of students' readiness. All in all, this study has different result compared to previous researches in more positive way.

The shift of face-to-face learning to face-to-screen learning in Speaking Class caused some anxieties to students. Though the respondents did not experience face-to-face meetings in Speaking Class before, the use of electronic devices, educational platforms, social media and internet connection needed great efforts and habituation. The challenges developed from technology, internet, devices, materials, material delivery, and assignments as has been mentioned in previous study [11] moderately affect respondents' anxiety since they were already familiar with the teaching technique. Nevertheless, feedbacks and assessment [11] still haunted the students. The results of questionnaire showed that students were moederatly anxious during online learning in Speaking Class compared to previous studies [4], [7], [8], [11]. This might because of the lecturer's strategy in teaching online has met students' expectation. Other, it might because of students could deal with the anxiety in their own ways.

\section{Conclusion}

Based on the results, each student certainly has the feeling of anxiety at different levels. The results showed that the students feel anxious because of four factors, namely fear of negative evaluation, test anxiety, and anxiety in online speaking classes. The anxiety could be seen from the unclear sentences produced, sweating, butterflies in the stomach, dry mouth, loss of words, and squeaky voice. However, the number of students who felt anxious was only a few numbers compared to previous studies. This was because of the teachers' technique in teaching online suits the students, the students were already technology literate, and able to cope with the anxiety in their own ways. The strategy used by students was preparing and learning for the upcoming meetings by making notes, doing self and peer-practice before the performance. During the performance, students tried to focus on the speaking materials, forget other thoughts which were not related to the topics, and apply breathing management to release the anxiety. 
These are the things that unseen on-screen that might help teachers, lecturers, and future researchers in developing future teaching and learning techniques or research that match the students and the situation.

\section{References}

[1] Komite Penanganan COVID-19, "FINAL_Pedoman Pembelajaran pada Semester Genap TA 2020_2021_20201120.pdf," Pedoman Pembelajaran pada Semester Genap Tahun Ajaran 2020/2021 di Masa Pandemi COVID-19. p. 14, 2020

[2] V. Gherhes, C. E. Stoian, M. A. Fărcasiu, and M. Stanici, "E-Learning vs . Face-To-Face Learning: Analyzing Students 'Preferences and Behaviors," Sustainability, vol. 13, no. 4381, pp. 1-15, 2021, doi: . https:// doi.org/10.3390/su13084381

[3] A. Y. Kurniawan and Indrawati, "Journal of English Language Teaching: Jan-Feb19," ELT Forum J. English Lang. TeachingJournal English Lang. Teach., vol. 10, no. 1, pp. 40-49, 2021, [Online]. Available: http://journal.unnes.ac.id/sju/index.php/elt.

[4] T. Pahargyan, "Students' Anxiety in Speaking English During DIstance Learning," UC J. ELT, Linguist. Lit. J., vol. 2, no. 1, pp. 1-13, 2021, doi: 10.24071/uc.v2i1.3240.

[5] Marriam Bashir; Muhammad Azeem; Ashiq Hussain Dogar, "Factor Effecting Students ' English Speaking Skills," Br. J. Arts Soc. Sci., vol. 2, no. January 2011, pp. 35-50, 2016.

[6] A. Paneerselvam and M. Mohamad, "Learners ' Challenges and English Educators ' Approaches in Teaching Speaking Skills in an ESL Classroom: A Literature Review," Creat. Educ., vol. 10, pp. 3299-3305, 2019, doi: 10.4236/ce.2019.1013253

[7] A. Hutabarat and D. C. Simanjuntak, "A Phenomenological Study: Speaking Anxiety Overwhelms English Learners," Acuity J. English Lang. Pedagog. Lit. Cult., vol. 4, no. 1, pp. 44-58, 2019, doi: 10.35974/acuity.v4i1.679.

[8] Najiha and B. Sailun, "An Analysis of Students' Speaking Anxiety in English Classroom at SMAN 2 Siak Hulu," Lect. J. Pendidik., vol. 12, no. 2, pp. 218-229, 2021.

[9] M. Bashori, R. van Hout, H. Strik, and C. Cucchiarini, "Web-based language learning and speaking anxiety," Comput. Assist. Lang. Learn., vol. 0, no. 0, pp. 1-32, 2020, doi: 10.1080/09588221.2020.1770293

[10] I. W. Antoro and D. Khazanah, "Speaking pada Mahasiswa Angkatan Tahun Pertama Jurusan Bahasa Inggris Fakultas Sastra Universitas Jember )," Artik. Ilm. Mhs., pp. 1-7, 2015.

[11] C. T. Hapsari, "Distance learning in the time of Covid-19: Exploring students' anxiety," ELT Forum J. English Lang. Teach., vol. 10, no. 1, 2021, doi: 10.15294/elt.v10i1.45756.

[12] J. B. Saputra, "an Analysis of Students' Speaking Anxiety Toward Their Speaking Skill," Premise J. English Educ., vol. 7, no. 1, p. 111, 2018, doi: 10.24127/pj.v7i1.1334.

[13] Mukhlash Abrar, "An Investigation Into Indonesian Efl University Students' Speaking Anxiety," JEELS J. English Educ. Linguist. Study, vol. 4, no. 2, pp. 221-248, 2017, doi: https://doi.org/10.30762/jeels.v4i2.358.

[14] M. Andrade and K. Williams, "Foreign Language Learning Anxiety in Japanese EFL University Classes: Physical, Emotional, Expressive, and Verbal Reactions," Sophia Jr. Coll. Fac. J., vol. 29, no. January 2009, pp. 1-24, 2009.

[15] A. Daud, F. Ras, N. Novitri, and C. P. Audia, "Factors Contributing to Speaking Anxiety: A Case Study of PreService English Teachers," J. Educ. Sci., vol. 3, no. 3, p. 412, 2019, doi: 10.31258/jes.3.3.p.412-422

[16] G. Öztürk and N. Gürbüz, "The Impact of Gender on Foreign Language Speaking Anxiety and Motivation," Procedia - Soc. Behav. Sci., vol. 70, pp. 654-665, 2013, doi: 10.1016/j.sbspro.2013.01.106.

[17] H. Nassaji, "Qualitative and descriptive research: Data type versus data analysis," Lang. Teach. Res., vol. 19, no. 2, pp. 129-132, 2015, doi: 10.1177/1362168815572747. 